\title{
The Governance Analysis of Islamic Boarding School in Preventing the Waqf Asset Misuse of Al-Amien Islamic Boarding School Sumenep
}

\author{
Mohammad Firlie Pranata*, Prof., Dr. Mohammad Nizarul Alim, Dr. Rita Yuliana \\ Economy and business faculty of Trunojoyo University, Madura, St. Raya Telang, PO.BOX 2 Kamal, \\ Bangkalan, Madura, Indonesia
}

*Corresponding Author: Mohammad Firlie Pranata, Economy and business faculty of Trunojoyo University, Madura, St. Raya Telang, PO.BOX 2 Kamal, Bangkalan, Madura, Indonesia

\begin{abstract}
Mohammad FirliePranata, Governance Analysis of Islamic Boarding Schools in the Context of Prevention of Misuse of Waqf Assets at Al AmienPrenduan Islamic Boarding School Sumenep. Guidance by Prof. Dr. Mohammad NizarulAlim, M.Sc., Ak., CA and Dr. Rita Yuliana, SE., MSA., CA., Ak., CFrA.

Al-Amien Islamic Boarding School PrenduanSumenep is one of the waqf managers for the benefit of the ummah, the Management of Al-AmienPrenduan Pesantren is a necessity. Guidelines for the 2006 National Committee on Governance Policy (KNKG) explain that every company must ensure that the principles of Good Corporate Governance (GCG) are applied to every aspect of the business and in all levels of the company. This article aims to find out the characteristics of waqf governance and prevention of asset misuse with good governance. The results show that the highest decision holder in the cottage is the Waqf Board, from the GCG Principl namely transparency, accountability, responsibility, independence and reasonableness known that the need for improvement of the control system on reporting on land management carried out by Implementing Maintenance and Expansion of Waqf Land (P3TW) so that there will be no misuse of assets in the future.
\end{abstract}

Keywords: GCG, Waqf, misappropriation Asset

\section{BACKGROUND OF STUDY}

The Indonesian waqf management needs to be fixed yet, though the law that rules the regulation is well maintained, the application process does not align properly. It means there needs to be a constructive understanding toward the law about waqf management that nadzir must do, (Muntaqo, 2015). Starting this initiative, means the fixation needs to proceed under the guidelines of waqf official statement that is concluded in law no. 41 year 2004 article 1 verse 3 that says 'waqf official statement is the statement of the wakifl's will delivered verbally and written to nadzhir to give their belongings as charity'. This waqf official statement is delivered in front of the board of waqf certificate maker (PPAIW) with two persons as witnesses. In case of the wakif was unavailable to attend to proclaim the statement, it is validated that they can point a representative with an authority letter and proved at least by two witnesses. According to article 32, the registration period and the announcement toward PPAIW for nadzhir to register the belongings of waqf to related institution is 7 working days for the latest as soon as the waqf statement is issued. The requirements are: (a) copy of waqf statement (b) letters and proofs of ownership and other related documents.

A special attention is also necessary on the waqf foundation administrative. They need to make sure about the accountability of mutawalli these are basic Islam perspective (wholehearted, trusted, reliable, and fair). These principals encourage mutawall is to practice perfection in managing the waqf assets in order to receive Allah"s blessings and society balance. Trusted principal encourages mutawalli to manage waqf assets acted asAllah"s messenger and assuming the property of waqf as a belief. Reliable principal is important for mutawalli in processing the waqf income distribution to determine the appropriate levels of waqf to the rightful receivers and himself, while fair principle is the fundamental aspect in making a decision (Ihsan, 2015). 
Al-Qure an is a guide to a well management. It can reach the goal by giving more value to personality and leadership skills, charismatic leaders in comparison of foundation infrastructure (Naqvidkk, 2011). Muqorobin, (2011) explains about fiqih of the profit management organization involves government, religious leader, business, community organization, and other communities that can implement profit organization or company well and clean.

Boarding school is one of the waqf managers. It is an essential institution for having a tremendous role in education in Indonesia. This successfulness is supported by independent financial factor through their productive enterprises and waqf asset productivity (Suhendi, 2018).

Related study done by Mu'allim (2015) shows that the waqf management model in Egypt has been an influence to waqf management in education institution in Indonesia. Enough successful number of the management and development prove this model is useful for waqf board of Indonesia Islam University and Gontor boarding school. This model is able to create „maslahah al ammah", which is public benefits for everyone.

Setiawan (2016) in his study, concludes that Al-Hikmah boarding school manages the waqf foundation synergistically, with traditional education management and the waqf benefits are implemented through activities that categorize in four aspects; economy, health, tools, education and religious activities. Meanwhile, the cash implementation study at BaitulMaal Hidayatullah and Social fund foundation Al-Falah is not productive yet because the waqf fund on both institution is consumptive, in form of materials for boarding school and mushaf Al-Qur"ean (Utami and Ismail, 2014). It is different from Siddiq"s study (2011) that states community is not totally helping to develop the religious social institution such as boarding school; this is because the boarding school ownership is unknown or even not entirely public property. This causes a problem in the development of waqf asset, not only the mixed asset of waqf status and not in fund raising, but also the unqualified nazhir does not have competence to be a professional.

Next study is from Niadkk. (2015) their study indicates that in several decades, the common misuse asset occurred in financial service industries; moreover, all the respondents assume that it is a serious situation. Majida"s study dkk (2014) supports the finding that asset misuse becomes a main public attention, it is also found that occurrence such as work vehicle misuse, computer, and facilities are personal-owned. According to the observation done at boarding school of Al-AmienPrenduan that happens to have many waqf assets and developed the creative enterprises, all the activities related to the foundation, institution, bureau, and business units are maintained every month and there is a meeting on Tuesdays in evaluating the boarding school. These factors could arise the asset decreasing misuse by the managers while the discovery of the problem is not solved.

Based on the law number 41, 2014 about waqf, it states that nadzir is the rightful message receiver from the waqif in form of waqf belongings to be manageable and developable according to the alignment. In accordance with Nadzhir Article 6 of the Waqf Law, consists: (a) individual, (b) organisation, and (c) firm. The study researcher found out that waqf certificate of Al-Amien Boarding School is not named after an organization or legal entity, but after the name of someone which is $\mathrm{Hj}$. Muhammad TidjaniDjauhari, the highest leadership of the assembly before Dr. KH. Ahmad FauziTidjani, this occurrence may concern the next generation would create a conflict.

Based on the observation done by the researcher, which is obtained from the maintenance implementers and waqf land extension (P3TW), it shows that the certificated waqf land is $76 \%$, and the uncertificated waqf land is 24

$\%$. The treasury administrator Al- Amien supports this statement, they say that there are several waqf lands which are still unclear for the location and not transferred by the title of ownership, but the certificates are listed in P3TW of Al-Amien.

Based on the explanation above, the researcher will conduct a different research than before. The researcher aims to understand the characteristics of the boarding school management related to sharia obedience in managing, taking responsibility on various activities, social funds, and their enterprises. While the decision making is placed on the waqf board, and asset outside of the boarding school that needs supervision and report in the management. In this case, it is essential to study about the management contribution in preventing the waqf asset misuses. 
The purpose of this study is to understand the characteristic of waqf management, the management contribution toward the waqf asset misuses of Al-Amien Boarding School in Sumenep.

\section{Method}

This study uses a qualitative approach with descriptive case study method. According to Yin (2014), this method has the nature of exposing with the purpose of obtaining the full picture about the event in certain places. Then, this study method is also appropriate to use on a research for a researcher who already receives the description or the early data about the researched issue.

The researcher selects the inside informant for this research to get optima and accurate information to answer the problem statement and meet the objectives of the study.

The informants is expected to be able to give their best answers and share their experience related the problem of the study. The data collection in the case study uses triangulation, which combines between observation, in depth interview, and documentation needed for the data.

\section{RESUlT AND DISCUSSION}

Al-Amien Islamic Boarding School Management Prenduan is a necessity that is carried out every day to reach out success in present and future, this good governance becomes reference of a corporation in implementing their daily operations to run smoothly. Based on National Policy Committee Guidelines Governance (KNKG) 2006, explains that every company must ensure that the principle of GCG is applied to each business aspect and in all ranks of the company. GCG principle, namely transparency, accountability, responsibility, independence and fairness and equality are needed to achieve sustainable business by paying attention to stakeholders.

\subsection{Transparency of Waqf Management}

The Al-Amien Boarding School Prenduan regularly delivers materials well information either mandatory financial report for interim and or semester, and or annual auditory. Each bureau of business unit of the boarding school must report the activity and finance result to the supervision board, then forwarded to the assembly of kiai regarding the report done once in a month, which is audited by the supervision board and independently managed.

Al-Amien, Islamic Boarding School Prenduan, has done a lot of cooperation and conducting various activities within the country and overseas, the number of honored guests visit proves this achievement. This can be seen and published on the official website of Al-Amien that is alamien.ac.id providing the latest information about the activities on the boarding school.

\subsection{Accountability of Waqf Management}

The waqf management context of Nadzir in Al-Amien, which implements separation to personal ownership rights and boarding school ownership rights and all legitimate waqf asset, will raise the awareness that their belongings are ownership rights of other, so the value will create bliss and wholeheartedness for waqif to do waqf, and share motivation to nadzhirin implementing the messages very well according the alignment.

The waqf board was officially founded around $80^{\circ} \mathrm{s}$, while the separation of the treasure was done in $70^{\text {ee }} \mathrm{s}$. It is inspired from the boarding school of Gontor. The accountability of Al-Amien Boarding School is separated based on the waqf management. Nadzhir becomes the highest assembly institution over all the control of waqf asset. However, the operational management establishes separated units P3TW (Implemetation, maintenance, waqf land extension), which takes care of administrative parts, do the extending land possibility and waqf lands management for boarding school buildings. Meanwhile, it is stated in law number 41, 2004 that nadzhir implements the job description about the waqf management.

\subsection{Responsibility of Waqf Management}

The Al-Amien Islamic Boarding School has a responsibility in term of owned-legitimate waqf land. The availability of economy and means bureau in covering the implementation of maintenance and waqf extending land (P3TW) is in effort to maximized extending land, in order the good development, which becomes a responsibility as a main contribution. 
P3TW also conducts data collection on waqf land, which later is possibly required by the leadership and the guardians. For instance, it would be P3TW"es responsibility to report, for the leaders who want to know the condition of the land. The name of the certificate owner above is still in the name of $\mathrm{KH}$. Muhammad TidjaniDjauhari. According to the law number 41, 2004 about waqf, it explains that nadzir is the receiver side of the waqif in form of waqf treasure to manage and develop in accordance with the law aligned. According to law article 6, nadziris formed as: (a) individual, (b) organization, and (c) legal institution. The study researcher found out that waqf certificate of Al-Amien Islamic

Boarding School is not named after the organization or legal institution but in the name of individual, it is H. Muhammad TidjaniDjauhari, the highest assembly of kyai before Dr. KH. Ahmad FauziTidjani. This matter concerns for the next generation to have conflicts.

The independent pillars of Al- Amien Islamic Boarding School Prenduan state:

Al-Amien Islamic Boarding School Prendual guarantees that management is carried out in a manner of independency, not to dominate each other, unaffected by certain interest and free from the stakeholder"s interest collision, government even theleaders.

The riasah council as the highest holding authorization in the determining the policy direction of the Al-Amien Islamic Boarding School Prenduan, expects the existence of good increasing quality in term of education, fostering, even the development of the human resources in boarding school environment for the future. In this case, which affects the students ${ }^{\text {ece }}$ satisfaction and community who concern about the sustainable education in Al-Amien (warkat, 2017).

The existence of Al-Amien Islamic Boarding School Prenduan is society"s significance without any personal interest toward the board of Riaasah, which boarding schooleswaqf and kyaies personal property areseparated regarding the waqf asset. The Al-Amien Islamic Boarding School is also not under the pressure of the government or even those who deliver waqf in form of cash orland.

\subsection{The Propriety of Al-Amien Islamic Boarding School Prenduan}

In Al-Amien Islamic Boarding school, it has been prepared for the regenerations to continue the nextkyaie"s will, namely a wan assembly which the members are the sons, sons-in-law of kyai and senior ustad.

Based on all the explanation described from chapter 4, it is clear that most of Al-Amien Islamic Boarding School es administrators tend to havedouble position; however, there are some of them not kyaires descendants. For instance, the ustads who have positively proved to be faithful and thebest for Al-Amien Islamic Boarding School.

This school is one the largest Islamic Boarding School that has a good management system, along with the waqf board, which covers the highest- decision making. It still has no standard financial report, but it is already appropriate with the procedure, moreover the waqf development of $\mathrm{Al}$ AmienPrenduan is not fully implemented by the waqf land. $38 \%$ of the land is unmanageable and empty, it is considered that human resources or natural sources and pillar of GCG, found out to appear the misuse of theasset on the Al-Amien Islamic Boarding School. This is because of the double position owned by some the administrators that causes a lot of the job to remain idle, for instance, the unknown location of waqf asset for the certificate has been issued.

\section{CONCLUSION}

Al-Amien Islamic Boarding School Prenduan is one the largest Islamic Boarding Schools that has a good system inside management of governance with the existence of waqf body to shelter as the highest decision maker.

Al-Amien Islamic Boarding School Prenduan still has no standards related to reporting finance, but the report has been aligned with procedure.

The management and development of Al-AmienPrenduan are not fully implemented; there is $38 \%$ of unmanageable waqf land that becomes empty until now because of human and natural resources.

The missuse asset of Al-Amien Islamic Boarding School happens more onto the administrators of the school, because of the double position, this case causes a lot of job to remain idle, such in P3TW, as 
the unknown location of waqf asset for the certificate has beenissued.

\section{SUGGESTION}

The Al-Amien Islamic Boarding School kyai assembly must establish a standard to report finance for it is to be more organized, and easily monitored by the school supervisions.

The implementers, maintenance and waqf extending land (P3TW) at the school are expected to give solution to $38 \%$ of unmanageable and empty land until now.

It is expected for the school to add more personnel in A "ewan Assembly or start a recruitment for the administrators or staff for a better future.

\section{REFERENCES}

[1] AnisaFitria, U., \&Munawar, I. (2014).Implement as iPengelolaan WakafTunai (Studipada Baitul MaalHidayatullah\&Yayasan Dana Sosial Al-Falah). JurnalIlmiahMahasiswaFakultasEkonomi Dan Bisnis, UniversitasBrawijaya, Indonesia, 3(1), 1-16.

[2] Burraey, M. A. Al. (2002). Islamic Prespective on Good Governance. International Conference on Good Governance: Perspective and Practice.

[3] Cahya, B. T. (2009). KilasKebijakan Good Corporate Governance Pada, VII, 15-28.

[4] Faozan, A. (2013). ImplementasiGoodCorporate Governance Dan PeranDewanPengawasSyariah Di Bank Syariah. La Riba, VII(1), 1-14.

[5] Hamdani.(2016). Good Corporate Governance.JurnalEkonomi Islam, 8, 71-86.

[6] Hashim, F., Mahadi, N. D., \&Amran, A. (2015). Corporate Governance andSustainability Practices in Islamic Financial Institutions: The Role of Country of Origin. ProcediaEconomics and Finance, 31(15), 36-43.https://doi.org/10.1016/S2212- 5671(15)01129-6

[7] Huda, N., Anggraini, D., Rini, N., \&Mardoni, Y. (2014). Akuntabilit as Sebagai Sebuah Solusi Pengelolaan Wakaf. Jurnal Akuntansi Multiparadigma, 5(3), 485-497.

[8] Ihsan, Hidayatul, \& Abdullah Ayedh.(2015). A Proposed Framework of Islamic Governance for Awqaf. Journal of Islamic Economics, Banking and Finance, 11(2), 117-132.

[9] Majid, R. A., Mohamed, N., Haron, R.,Omar, N. B., \&Jomitin, B. (2014). Misappropriation of Assets in Local Authorities: A Challenge to Good Governance. Procedia - Social and Behavioral Sciences, 164(August), 345-350. https://doi.org/10.1016/j.sbspro.201 4.11.086

Citation: Mohammad Firlie Pranata, et.al. "The Governance Analysis of Islamic Boarding School in Preventing the Waqf Asset Misuse of Al-Amien Islamic Boarding School Sumenep" International Journal of Managerial Studies and Research (IJMSR), vol 7, no. 12, 2019, pp. 91-95. doi: http://dx.doi.org/10.20431/23 49-0349.0712012.

Copyright: (C) 2019 Authors. This is an open-access article distributed under the terms of the Creative Commons Attribution License, which permits unrestricted use, distribution, and reproduction in any medium, provided the original author and source are credited. 